\title{
Diagnosis of adult polycystic kidney disease by genetic markers and ultrasonographic imaging in a voluntary family register
}

R G Elles, K A Hodgkinson, N P Mallick, D J O'Donoghue, A P Read, S Rimmer, E A Watters, $R$ Harris

\begin{abstract}
Diagnosis of autosomal dominant adult polycystic kidney disease (APKD) is possible by ultrasonographic scanning (USS) or by using DNA markers linked to the PKD1 locus. Ultrasonography is complicated by the age dependent penetrance of the gene and linkage studies are subject to recombination errors owing to meiotic crossing over and locus heterogeneity.
\end{abstract}

This study draws on data collected from a voluntary family register of APKD over 10 years. Records of 150 families were examined, ultrasound reports were obtained from 242 people at $50 \%$ prior risk, and 37 families were typed for DNA markers. The fraction of APKD resulting from loci unlinked to PKD1 (designated PKD2 here) was calculated at $\mathbf{2 . 9 4 \%}$ (upper confidence limit $\mathbf{8 . 6 2} \%$ ). Some subjects who were negative on initial scan later gave a positive scan, but there was no example of a definite gene carrier aged over 30 giving a negative scan. In families large enough for linkage analysis, most people who were at $\mathbf{5 0 \%}$ prior risk could be given a final risk below $5 \%$ or above $95 \%$, by using combined ultrasound and DNA studies.

( $(\mathcal{H}$ Med Genet 1994;31:115-120)

Adult polycystic kidney disease is one of the commonest serious autosomal dominant diseases, affecting between 1 in 1000 and 1 in 2500 white people. Renal function is impaired as fluid filled cysts increase in size and number, replacing tissue of the renal cortex with nonfunctional material and damaging the interstitial cortex. Of all patients requiring kidney transplants, $6 \%$ to $10 \%$ suffer end stage renal failure as a result of APKD. ${ }^{12}$ The gradual development of cysts gives the disease a marked age dependent penetrance, and the course is very variable. The risk of end stage renal failure has been estimated as $2 \%$ before the age of $40,23 \%$ at the age of 50 , and $48 \%$ at 73 years. $^{3}$

Few people request prenatal diagnosis of APKD, but presymptomatic screening is important because complications of APKD threaten the health of gene carriers if untreated. ${ }^{45}$ Presymptomatic diagnosis has been possible for some time through renal imaging. Ultrasonographic scanning is the method of choice, being safe, inexpensive, and non-invasive. A crucial question for genetic counselling is the sensitivity of ultrasound scanning for detecting early manifestations of the disease. In an early study using first generation technology, Bear et $a l^{6}$ analysed data on 17 families from Newfoundland, Canada. For subjects at $50 \%$ prior risk of carrying the APKD gene, they reported false negative rates in the second and third decades of 0.25 and $0 \cdot 12$ respectively. In a more recent study in the same families, Bear $e t a l$ have revised their figures for these age classes to 0.08 and 0 .

DNA based diagnosis became possible in 1985 when Reeders et $a l^{8}$ showed linkage between the APKD locus (PKD1) and the $\alpha$ globin locus on chromosome 16p13.3. Since then, highly informative markers flanking the PKD1 locus have been defined, allowing accurate presymptomatic diagnosis at any age. ${ }^{89}$ A problem for DNA marker studies is the existence of families in which APKD does not segregate with $16 \mathrm{p}$ markers. ${ }^{111}$ This unlinked form is called PKD2, but the location of the gene(s) is unknown*. The proportion of unlinked APKD families has been estimated as $4 \%$ and $14 \%$ in North America and Europe respectively. ${ }^{12-14}$ Presymptomatic or prenatal risk estimates are now based on combining age dependent ultrasound data with information from $16 \mathrm{p}$ markers, allowing for the possibility that the disease is not linked to PKD1. ${ }^{1516}$

In the North Western Health Region of the UK a voluntary genetic family register was established in 1980, covering a population of 4 million. We have studied 150 families ascertained through the register. This cohort enables us to estimate the proportion of unlinked (PKD2) kindreds in the study population, to study the reliability of ultrasonographic scanning using modern imaging equipment, and to examine the concordance between USS data and genetic markers. Combining the data permits an overview of the effectiveness of molecular and ultrasonographic techniques combined in presymptomatic and prenatal diagnosis.

\section{Materials and methods}

ASCERTAINMENT AND SELECTION OF FAMILIES All families were ascertained through an index patient referred from a renal unit in the north

* The PKD2 gene has very recently been localised to chromosome 4q (Peters et al. Nature Genet 1993;5:359-62, Kimberling et al. Genomics, in press). 
Table 1 Structure of the data set. Of the 150 family register records examined, 36 families with only one case of diagnosed APKD were excluded from analysis. The total of subjects at $50 \%$ risk and those diagnosed affected includes index cases in this table

\begin{tabular}{llll}
\hline $\begin{array}{l}\text { Families } \\
\text { examined }\end{array}$ & $\begin{array}{l}\text { Families } \\
\text { excluded }\end{array}$ & $\begin{array}{l}\text { Subjects at } \\
50 \% \text { risk }\end{array}$ & $\begin{array}{l}\text { Diagnosed APKD } \\
\text { clinically or by USS }\end{array}$ \\
\hline 150 & 36 & 1412 & 522 \\
\hline
\end{tabular}

west of England, who was then contacted by the Regional Genetics Service. Register records and USS reports from 150 families were examined (table 1). Families with only one subject diagnosed were not included in the analysis to prevent phenocopies or new mutations entering the data set. For the multiplex families, all people at $50 \%$ prior risk were counted, and total numbers and numbers affected, excluding the index case, were counted for each age group 0-9, 10-19, 20-29, 30-39, $40-49$, and $50+$.

CALCULATION OF THE PROPORTION OF FAMILIES NOT LINKED TO THE PKD1 LOCUS

Families were typed with two or more of the DNA markers listed in table 2, to find informative flanking markers. Following Sandkuijl (personal communication) we calculated the likelihood of each pedigree using two alternative maps:

$$
\begin{gathered}
\text { A-- }-\theta_{1}---D---\theta_{2}---B \text { and } \\
D---(\theta=0 \cdot 5)---A---\left(\theta_{1}+\theta_{2}\right)---B
\end{gathered}
$$

where $\mathrm{D}$ is the disease and $\mathrm{A}$ and $\mathrm{B}$ are markers known to flank the PKD1 locus with recombination fractions $\theta_{1}$ and $\theta_{2}$ respectively. Linkmap $^{25}$ was used to calculate these likelihoods. The ratio of the two likelihoods gives the odds PKD1:non-PKD1 for that family. Some families were informative only for a single marker, in which case Mlink was used. The odds ratio was converted into a probability of non-PKD1 using a prior probability of nonlinked disease of $0 \cdot 14$, from the European study. ${ }^{14}$

\section{ULTRASOUND DETECTION RATES}

Ultrasonographic reports were noted from persons at $50 \%$ prior risk who had no previous history of symptoms to bring them forward for clinical examination. Mostly these were people who volunteered for presymptomatic screening as a result of contact with the Family

Table 2 Genetic markers used in this study

\begin{tabular}{llllll}
\hline $\begin{array}{l}\text { Locus } \\
\text { name }\end{array}$ & $\begin{array}{l}\text { Marker } \\
\text { name }\end{array}$ & $\begin{array}{l}\text { Marker } \\
\text { type }\end{array}$ & Alleles & $\begin{array}{l}\text { Distance from } \\
\text { PKD1 }(c M)\end{array}$ & Reference \\
\hline D16S85 & 3'aHVR & VNTR & Many & 5 & 17 \\
D16S84 & GGG1 & RFLP & 3 & 1 & 18 \\
D16S145 & pNL56S & RFLP & 4 & 1 & 19 \\
D16S283 & SM7 & (CA) & 11 & 1 & 20 \\
D16S291 & 16AC2.5 & (CA) & 10 & 1 & 21 \\
D16S125 & SM6A & (CA) & 6 & 1 & $*$ \\
D16S94 & VK5 & RFLP & 2 & 1 & 22 \\
& VK5AC & RFLP & 2 & 1 & 23 \\
D16S80 & p24-1 & RFL) & 5 & 1 & 23 \\
\end{tabular}

Marker types: RFLP, restriction fragment length polymorphism; VNTR, variable number of tandem repeats; (CA), microsatellite. Marker order: 16pter-D16S85-(D16S84,D16S145)PKD1-(D16S283, D16S291, SM6A)-D16S125-D16S94-D16S80-16cen.

* P Harris, personal communication.
Register. Index cases and all subjects presenting with symptoms were excluded from the analysis of ultrasound error rates. Subjects were assigned an age class according to the date when they were first examined by ultrasonography. Scan reports were classified as positive, negative, or equivocal. Following Bear et $a l,{ }^{6}$ the criterion for a positive report was at least one cyst in each kidney and one kidney having more than one cyst. Most of the ultrasonographic scans were performed by a single experienced consultant radiologist using either a Hitachi EUB $25 \mathrm{M}$ scanner with a $3.5 \mathrm{MHz}$ linear array or an Acuson 128 scanner with a $3.5 \mathrm{MHz}$ linear array or sector probe.

For each age class the frequency of false negative USS diagnosis was estimated by comparing observed and expected rates of positive results. The expected frequency of positive results depends on age. It is always less than $50 \%$ because only asymptomatic people are considered. In a group of $\mathrm{N}$ people all at $50 \%$ prior risk, of whom A have already presented with symptoms, the proportion of gene carriers among asymptomatic people is $\left\{\left(\frac{1}{2} \mathbf{N}\right)-\mathbf{A}\right\} /$ (N-A). This was compared with the proportion of people examined whose scan was positive (equivocal scans were counted as negative for this purpose).

A $95 \%$ confidence interval was calculated for the observed rate of positive scans (observed $\pm 1.96 \times \sqrt{ }(\mathrm{pq} / \mathrm{n})$, where $\vee(\mathrm{pq} / \mathrm{n})$ is the binomial standard deviation). Complementing this statistical approach to detecting false negatives, individual cases were noted where the diagnosis had changed on repeated scans.

\section{CONCORDANCE BETWEEN USS AND GENETIC} MARKERS

High risk and low risk haplotypes were assigned by inspection in each family. Marker and ultrasound data were classed as conflicting when somebody inherited a haplotype nonrecombinant for markers spanning the PKD1 locus, but did not have the expected scan result. Cases where there was a marker-marker recombinant, so that the haplotype could not be unambiguously defined as high risk or low risk, were not counted as conflicting.

CALCULATION OF INDIVIDUAL RISKS

Individual risks combining marker and ultrasound information were calculated for 65 asymptomatic subjects from 30 families. Risks were calculated using Mlink, using conservative liability classes based on the study of Bear et al (all asymptomatic persons under 20 years a risk of 0.5 of having the APKD gene and allowing an error rate of 0.08 for persons over 20 years with negative USS). The Mlink risk was then modified to allow for the possibility that the disease was not PKD1. If the risk of PKD2 in the family is $x \%$, this adds a risk of false results of $x / 2 \%$, since half the time the $16 \mathrm{p}$ markers will segregate with the unlinked disease just by chance. 
Table 3 Probability for each family that APKD is not linked to the PKD1 locus. Markers are listed in table 2. The final column combines the odds ratio with a prior probability of 0.14

\begin{tabular}{|c|c|c|c|c|}
\hline Family & Distal marker & Proximal marker & Odds linked:not linked & $\begin{array}{l}\text { Probability } \\
\text { non-linked }\end{array}$ \\
\hline $\begin{array}{l}100 \\
101 \\
102 \\
104 \\
106 \\
108 \\
109 \\
117 \\
123 \\
125 \\
126 \\
138 \\
145 \\
148 \\
158 \\
159 \\
168 \\
169 \\
172 \\
177 \\
181 \\
184 \\
800 \\
802 \\
813 \\
814 \\
817 \\
818 \\
819 \\
822 \\
823 \\
824 \\
825 \\
829 \\
837 \\
838 \\
848\end{array}$ & $\begin{array}{l}\text { S85 } \\
\text { S85 } \\
\text { S85 } \\
\text { S85 } \\
\text { S85 } \\
\text { S85 } \\
\text { S85 } \\
\text { S85 } \\
\text { S85 } \\
\text { S85 } \\
\text { S85 } \\
\text { S85 } \\
\text { NI } \\
\text { S85 } \\
\text { S85 } \\
\text { S85 } \\
\text { NI } \\
\text { S85 } \\
\text { S85 } \\
\text { S85 } \\
\text { S85 } \\
\text { S85 } \\
\text { S85 } \\
\text { S84 } \\
\text { S84 } \\
\text { S85 } \\
\text { S84 } \\
\text { S85 } \\
\text { S85 } \\
\text { S85 } \\
\text { NI } \\
\text { S85 } \\
\text { S85 } \\
\text { S85 } \\
\text { S85 } \\
\text { NI } \\
\text { S84 }\end{array}$ & $\begin{array}{l}\text { S125 } \\
\text { S125 } \\
\text { S283 } \\
\text { S125 } \\
\text { S80 } \\
\text { S125 } \\
\text { S125 } \\
\text { S80 } \\
\text { S283 } \\
\text { S283 } \\
\text { S125 } \\
\text { S125 } \\
\text { NI } \\
\text { S80 } \\
\text { S80 } \\
\text { S125 } \\
\text { NI } \\
\text { S125 } \\
\text { S283 } \\
\text { S283 } \\
\text { S283 } \\
\text { S125 } \\
\text { S94 } \\
\text { S94 } \\
\text { S94 } \\
\text { S80 } \\
\text { S28 } \\
\text { NI } \\
\text { S80 } \\
\text { S125 } \\
\text { NI } \\
\text { S283 } \\
\text { SM6A } \\
\text { S125 } \\
\text { S125 } \\
\text { S291 } \\
\text { S125 }\end{array}$ & $\begin{array}{r}10 \cdot 18: 1 \\
16 \cdot 33: 1 \\
34 \cdot 43: 1 \\
3 \cdot 76: 1 \\
1502 \cdot 09: 1 \\
1 \cdot 04: 1 \\
3 \cdot 58: 1 \\
1 \cdot 80: 1 \\
1: 1 \cdot 17 \\
1 \cdot 83: 1 \\
33 \cdot 52: 1 \\
1 \cdot 69: 1 \\
1: 1 \\
21 \cdot 72: 1 \\
1 \cdot 53: 1 \\
6 \cdot 91: 1 \\
1: 1 \\
1 \cdot 59: 1 \\
3 \cdot 56: 1 \\
3 \cdot 38: 1 \\
3 \cdot 58: 1 \\
1 \cdot 97: 1 \\
7 \cdot 53: 1 \\
11 \cdot 71: 1 \\
23 \cdot 39: 1 \\
12 \cdot 28: 1 \\
1 \cdot 90: 1 \\
1: 1 \cdot 46 \\
1 \cdot 81: 1 \\
1 \cdot 83: 1 \\
1: 1 \\
1 \cdot 83: 1 \\
1: 347 \\
1 \cdot 83: 1 \\
1 \cdot 27: 1 \\
1 \cdot 68: 1 \\
2 \cdot 00: 1\end{array}$ & $\begin{array}{l}0.0144 \\
0.0091 \\
0.0044 \\
0.0405 \\
0.0001 \\
0.1256 \\
0.0528 \\
0.0766 \\
0.1488 \\
0.0754 \\
0.0045 \\
0.0812 \\
0.1300 \\
0.0068 \\
0.0890 \\
0.0211 \\
0.1300 \\
0.0859 \\
0.0403 \\
0.0424 \\
0.0731 \\
0.0705 \\
0.0194 \\
0.0126 \\
0.0063 \\
0.0120 \\
0.0751 \\
0.1790 \\
0.0763 \\
0.0755 \\
0.1300 \\
0.0755 \\
0.9811 \\
0.0755 \\
0.1053 \\
0.0817 \\
0.0686\end{array}$ \\
\hline
\end{tabular}

$\mathrm{NI}=$ not informative.
Table 5 Results of sequential scanning. Numbers of people whose scan diagnosis changed (from negative to equivocal or positive, or from equivocal to positive) as a proportion of the total number of people who had sequential scans

\begin{tabular}{lllll}
\hline & \multicolumn{4}{l}{ Age at subsequent scan } \\
\cline { 2 - 5 } Age at first scan & $0-9$ & $10-19$ & $20-29$ & $30-39$ \\
\hline $0-9$ & $1 / 2$ & $0 / 0$ & $0 / 0$ & $0 / 0$ \\
$10-19$ & & $2 / 4$ & $2 / 12$ & $1 / 1$ \\
$20-29$ & & & $2 / 11$ & $1 / 3$ \\
$30-39$ & & & & $1 / 6$ \\
\hline
\end{tabular}

this global calculation gives no evidence of a significant number of false negative scans after the age of 10 . Table 5 shows scan results from 39 subjects who had two or more USS separated by one year or more. Twenty-nine of the 39 subjects had negative first scans confirmed on repeat. Ten changed scan status: either the first scan was equivocal and the second positive, or the first scan was negative and the second positive or equivocal. The ages at first and second scans are shown. Two more people were excluded from this analysis because their two scans were probably not done on comparable instruments. These rates of change cannot be assumed to apply generally, because there may have been suspicions which indicated a repeat scan.

\section{COMPARISON OF DNA AND ULTRASOUND} RESULTS

Table 6 shows the findings in 78 subjects with informative DNA and ultrasound results. There were five evident discrepancies. Two of these were from family 825 which is probably segregating the unlinked disease (see above). Two, from two different families, inherited a high risk haplotype but were negative on scan (table 6). One further person (subject 33 in family 106) had a low risk haplotype and an equivocal scan. between 1.1 and 1.5 in favour of non-linkage to PKD1 (translating into posterior probabilities of 0.15 and 0.18 respectively). No other informative family has any significant probability of being unlinked. Thus 1 out of 34 of our families probably has non-PKD1 disease.

OBSERVED AND EXPECTED POSITIVE SCANS

Table 4 sets out the findings in each age group. Except in the 0-9 year olds and the small number scanned over the age of 50 , the observed frequency of positive scans was at least as high as the expected proportion of gene carriers, calculated as explained above. Thus

Table 4 The results of ultrasonographic screening. See Methods section for methods of calculation

\begin{tabular}{|c|c|c|c|c|c|c|c|c|}
\hline \multirow[t]{2}{*}{ Age class } & \multirow[t]{2}{*}{ No } & \multirow[t]{2}{*}{ No affected } & \multicolumn{4}{|c|}{ USS examination } & \multicolumn{2}{|c|}{ USS + ve rate } \\
\hline & & & No & $+\mathrm{ve}$ & $-\mathrm{ve}$ & $?$ & Exp & Obs $\pm 95 \% \mathrm{CI}$ \\
\hline $\begin{array}{c}0-9 \\
10-19 \\
20-29 \\
30-39 \\
40-49 \\
>50\end{array}$ & $\begin{array}{l}149 \\
156 \\
198 \\
165 \\
126 \\
348\end{array}$ & $\begin{array}{r}3 \\
20 \\
39 \\
50 \\
54 \\
75\end{array}$ & $\begin{array}{l}17 \\
53 \\
96 \\
51 \\
15 \\
10\end{array}$ & $\begin{array}{r}4 \\
32 \\
44 \\
21 \\
3 \\
3\end{array}$ & $\begin{array}{r}10 \\
17 \\
50 \\
30 \\
12 \\
7\end{array}$ & $\begin{array}{l}3 \\
4 \\
2 \\
0 \\
0 \\
0\end{array}$ & $\begin{array}{l}0.490 \\
0.426 \\
0.377 \\
0 \cdot 283 \\
0.125 \\
0.363\end{array}$ & $\begin{array}{l}0.235 \pm 0 \cdot 201 \\
0.604 \pm 0 \cdot 132 \\
0 \cdot 458 \pm 0 \cdot 100 \\
0 \cdot 412 \pm 0 \cdot 135 \\
0 \cdot 200 \pm 0 \cdot 202 \\
0.300 \pm 0 \cdot 284\end{array}$ \\
\hline Total & 1142 & 241 & 242 & 107 & 126 & 9 & & \\
\hline
\end{tabular}

Table 6 Comparison of findings by scan and DNA markers. One person (subject 33 in family 106 ) with a low risk haplotype but an equivocal ultrasound finding has been classed as negative

\begin{tabular}{llcc}
\hline Age group & PKD1 haplotype & +ve on scan & - ve on scan \\
\hline$<30$ years & High risk & 27 & $2^{*}$ \\
& Low risk & $1^{*}$ & 28 \\
> 30 years & High risk & 1 & 1 \\
& Low risk & 0 & 20 \\
Total & High risk & 28 & 3 \\
& Low risk & 1 & 48
\end{tabular}

* These categories each include one subject from family 825 which is probably segregating PKD2. 
failure of the gene to manifest as a diagnosed complaint.

PROPORTION OF FAMILIES NOT LINKED TO PKDI One out of 34 informative families (table 3 ) probably has the unlinked disease, giving a rate of 0.029 (upper $95 \%$ confidence limit $0.086)$. This latter figure $(0.086)$ has been used as the prior probability in subsequent individual risk calculations. Our figure agrees with estimates from North America $(0.04)^{12}$ and Scotland $(0.03),{ }^{26}$ but is lower than the European estimate of $0 \cdot 14 .^{14}$ Parfrey et al ${ }^{13}$ suggested that the unlinked disease shows a milder course than PKD1. This would lead to an increased proportion of non-PKD1 disease among "sporadic" cases and kindreds with low numbers of clearly affected subjects. These families are less suitable for linkage analysis. Thus it is possible that there is a selective bias against the inclusion of non-PKD1 families in linkage based clinical studies.

FALSE NEGATIVE RATE OF ULTRASONOGRAPHY Realistic genetic counselling of family members at risk of APKD requires knowledge of the risk that a gene carrier will give a negative ultrasonograph. This error rate comes partly from failure to see cysts which are there, and partly from late development of cysts. The rate of development might be different in PKD1 and PKD2. The most quoted error rates come from the work of Bear $e t a l^{6}$ on 17 kindreds in Newfoundland. In the second and third decades these rates were calculated as $25 \%$ and $12 \%$ respectively. Scanning technology has improved since that study. The more recent study of Bear et al (based only on families with linkage results suggesting PKD1) revised the error rates to $8 \%$ in the second decade and approaching zero in the third decade and thereafter.

Our data broadly agree with these updated findings of Bear et al. ${ }^{7}$ Statistically we did not see false negative scans after the age of 10 , although anecdotally there were cases. We calculated $95 \%$ confidence intervals as explained above for the observed positive rate. Throughout the 10-39 age groups, the lower confidence limit of observed positives was equal to or greater than the expected frequency (table 4); thus this approach does not point to the presence of a significant false negative rate. These statistics are based on small numbers and on certain assumptions. We necessarily calculated the expected rate from the whole of the age group, including people not scanned. We assumed that the proportion of gene carriers in the subset examined by USS was the same as among the whole age group. This assumption might be wrong: some people may have presented for screening because they had noticed symptoms, or conversely people with minor symptoms might have declined screening to avoid confirming their fears. In the absence of data, it is impossible to say whether either of these biases occurred. Anecdotally we have detected false negative tests in certain subjects over 10 years old, from the data on repeat scans (table 5) and from the comparison of genetic marker data with ultrasonography (table 6). Table 5 shows 10 asymptomatic subjects whose scan status changed on repeat examination. Seven out of these 10 subjects developed imageable renal cysts or an abnormal cortex appearance (equivocal finding) in the second or third decades. We discourage screening in asymptomatic children, hence the small number scanned in the $0-9$ age group, who otherwise would no doubt have produced many cases of changed scan reports. Clearly a negative scan before the age of 30 does not exclude risk of APKD.

CONCORDANCE BETWEEN GENETIC MARKER AND ULTRASONOGRAPHIC DATA

The concordance between genetic marker and USS data in our series is strong (table 6) although there were a number of conflicts. Two members of family 825 show nonconcordance. One is clearly affected and one is unaffected. The disease in this family is probably not PKD1 (table 3). Three other cases of non-concordance have occurred. Subject 4 from family 138 is aged 26 and has inherited high risk close flanking markers despite having four negative USS between the ages of 18 and 24. Mlink ${ }^{17}$ gives this subject a $>98 \%$ risk of carrying the APKD gene despite the conflicting information. Non-penetrance is the likely explanation of this false negative result. In family 814 , subject 8 has had two negative scans at the age of 52, yet she has the same high risk haplotype as her affected sib. The disease in this family is almost certainly PKD1 (table 3). However, their parents are dead, so an alternative to non-penetrance is that the affected parent was homozygous for these marker alleles. Person 33 from family 106 was originally diagnosed as affected but has the low risk haplotype. This large family, which has previously been described, ${ }^{15}$ has unambiguous PKD1. Reassessment of the ultrasound data showed the cysts were observed in only one kidney (so this case did not meet the diagnostic criteria of Bear et al), and the subject has not reported any symptoms. The likely explanation is a false positive assignment of APKD. Reeders $e t a l^{77}$ have calculated that the false positive rate of ultrasonographic diagnosis may be as high as $2 \%$.

Table 5 includes very few people aged over 30 who had a high risk haplotype that could be compared with USS. In almost all of these small families, two affected people are "used up" to establish the linkage phase of the markers; therefore there are often no other affected people who can be scored independently.

In summary, among the USS negative group there are 3/51 cases with a high risk of APKD from DNA studies. One case can be explained by genetic heterogeneity, leaving one or possibly two cases apparently the result of failure of gene carriers to manifest renal cysts. The rate of false negative scans was $1 / 29$ or 0.034 (upper confidence limit $0 \cdot 10$ ) in the 
Table 7 The final risks for subjects at 50\% prior risk of APKD based on scan findings and DNA marker analysis

\begin{tabular}{|c|c|c|c|c|c|c|c|}
\hline Family & Person & Markers used & Age at scan & Scan result & Risk by Mlink & Prob PKD2 & Overall risk \\
\hline \multirow[t]{3}{*}{100} & 04 & S85/S125 & 50 & - ve & 0.00466 & \multirow[t]{4}{*}{0.0144} & 0.01186 \\
\hline & 06 & S85/S125 & 48 & - ve & 0.00466 & & 0.01186 \\
\hline & 18 & S $85 / \mathrm{S} 125$ & - & ND & 0.99906 & & 0.99186 \\
\hline \multirow{5}{*}{101} & 20 & S85/S125 & 22 & - ve & 0.00008 & & 0.00728 \\
\hline & 13 & $\mathrm{~S} 85 / \mathrm{S} 125$ & 19 & - ve & 0.00061 & \multirow[t]{5}{*}{0.0091} & 0.00516 \\
\hline & 14 & $\mathrm{~S} 85 / \mathrm{S} 125$ & - & ND & 0.95262 & & 0.94807 \\
\hline & 15 & S85/S125 & 5 & - ve & 0.00061 & & 0.00516 \\
\hline & 16 & S85 & 20 & - ve & 0.00753 & & 0.01208 \\
\hline 104 & $\begin{array}{l}17 \\
05\end{array}$ & S85 & 19 & - ve & 0.05433 & & 0.05888 \\
\hline \multirow{10}{*}{106} & $\begin{array}{l}10 \\
17\end{array}$ & S84 & 27 & $\begin{array}{l}-\mathrm{ve} \\
\mathrm{ND}\end{array}$ & 0.00087 & \multirow{10}{*}{0.0001} & 0.00097 \\
\hline & 19 & $\begin{array}{l}\text { S85/S80 } \\
\text { S85/S80 }\end{array}$ & $\overline{-}$ & $\begin{array}{l}\text { ND } \\
\text { ND }\end{array}$ & 0.00276 & & 0.00281 \\
\hline & 21 & $\begin{array}{l}\text { S85/S80 } \\
\text { S85/S80 }\end{array}$ & 35 & $\begin{array}{l}\text { ND } \\
\text { - ve }\end{array}$ & 0.00276 & & 0.00281 \\
\hline & 22 & $\begin{array}{l}\text { S85/S80 } \\
\text { S85/S80 }\end{array}$ & 25 & $\begin{array}{l}\text { - ve } \\
\text { - ve }\end{array}$ & 0.00031 & & 0.00036 \\
\hline & 23 & $\begin{array}{l}\text { S85/S80 } \\
\text { S85/S80 }\end{array}$ & 30 & $\begin{array}{l}\text { - ve } \\
\text { - ve }\end{array}$ & 0.00104 & & $\begin{array}{l}0.00109 \\
0.00036\end{array}$ \\
\hline & 25 & $\begin{array}{l}\text { S } 85 / S 80 \\
\text { S } 85 / S 125\end{array}$ & - & $\begin{array}{l}\text { - ve } \\
\text { ND }\end{array}$ & 0.00031 & & $\begin{array}{l}0.00036 \\
0.00251\end{array}$ \\
\hline & 26 & S85/S125 & - & $\begin{array}{l}\text { ND } \\
\text { ND }\end{array}$ & 0.00236 & & $\begin{array}{l}0.00251 \\
0.99711\end{array}$ \\
\hline & 27 & S $85 / S 125$ & 22 & $\begin{array}{l}\text { ND } \\
\text {-ve }\end{array}$ & 0.99716 & & $\begin{array}{l}0.99711 \\
0.00010\end{array}$ \\
\hline & 30 & S85/S80 & 23 & $\begin{array}{l}\text { - ve } \\
\text { - ve }\end{array}$ & 0.00005 & & $\begin{array}{l}0.00010 \\
0.01174\end{array}$ \\
\hline & 33 & S $85 / S 125$ & 21 & ? & 0.01169 & & $\begin{array}{l}0.01174 \\
0.00060\end{array}$ \\
\hline 109 & 04 & S $85 / S 125$ & 27 & ? ve & $\begin{array}{l}0.00055 \\
0.00115\end{array}$ & 0.0528 & $\begin{array}{l}0.00000 \\
0.02755\end{array}$ \\
\hline 117 & 03 & S $85 / S 125$ & 22 & - ve & & $\begin{array}{l}0.0528 \\
0.0766\end{array}$ & $\begin{array}{l}0.02135 \\
0.04965\end{array}$ \\
\hline 123 & 05 & $\mathrm{~S} 85 / \mathrm{S} 283$ & 24 & - ve & $\begin{array}{l}0.01135 \\
0.00456\end{array}$ & 0.1488 & $\begin{array}{l}0.04903 \\
0.07896\end{array}$ \\
\hline 125 & 03 & S85 & 23 & $-v e$ & 0.00018 & 0.0754 & 0.03788 \\
\hline \multirow[t]{2}{*}{126} & 05 & $\mathrm{~S} 85 / \mathrm{S} 125$ & 36 & -ve & 0.00008 & \multirow[t]{2}{*}{0.0045} & 0.00233 \\
\hline & 18 & S $85 / S 125$ & 22 & - ve & 0.01496 & & 0.01721 \\
\hline \multirow[t]{3}{*}{138} & 04 & S85/S125 & 26 & $-v e$ & 0.99392 & \multirow[t]{3}{*}{0.0812} & 0.95332 \\
\hline & 05 & S85/S 125 & 21 & - ve & 0.00005 & & 0.04065 \\
\hline & 07 & S $85 / S 125$ & 19 & $-v e$ & 0.00382 & & 0.04442 \\
\hline 145 & 05 & S85/S 125 & 32 & -ve & 0.08000 & 0.0862 & $0 \cdot 12310$ \\
\hline \multirow{2}{*}{148} & 08 & S85 & 18 & $?$ & 0.00513 & \multirow{2}{*}{0.0068} & 0.00853 \\
\hline & 13 & S85 & 23 & - ve & 0.00026 & & 0.00366 \\
\hline \multirow[t]{2}{*}{158} & 04 & S85/S80 & 38 & - ve & 0.00721 & 0.0890 & 0.05171 \\
\hline & 05 & S85/S80 & 32 & - ve & 0.15279 & & $0 \cdot 19729$ \\
\hline 159 & 03 & S $84 / \mathrm{S} 125$ & 29 & - ve & 0.00004 & 0.0211 & 0.01059 \\
\hline & 04 & S84/S 125 & 31 & - ve & 0.00004 & & 0.01059 \\
\hline & 06 & S84/S 125 & 25 & -ve & 0.00001 & & 0.01056 \\
\hline & 07 & S84/S125 & 22 & $-v e$ & 0.00001 & & 0.01056 \\
\hline 168 & 03 & S85/S125 & 18 & - ve & 0.00212 & 0.0862 & 0.04522 \\
\hline 172 & 03 & S85/S283 & 42 & - ve & 0.00138 & 0.0403 & 0.02153 \\
\hline 177 & 03 & S85/S283 & 33 & - ve & 0.00005 & 0.0424 & 0.02125 \\
\hline & 04 & S85/S283 & 33 & - ve & 0.00005 & & 0.02125 \\
\hline 181 & 05 & S85/S283 & 42 & - ve & 0.00100 & 0.0731 & 0.03755 \\
\hline & 08 & S85/S283 & 17 & - ve & 0.02500 & & 0.06155 \\
\hline 800 & 05 & S85/S283 & 36 & - ve & 0.00038 & 0.0194 & 0.01008 \\
\hline & 10 & S $85 /$ S 283 & - & ND & 0.50478 & & 0.51448 \\
\hline 802 & 06 & S $85 / \mathrm{S} 125$ & 35 & - ve & 0.50070 & 0.0126 & 0.50700 \\
\hline & 08 & S85/S125 & 30 & - ve & 0.04475 & & 0.05105 \\
\hline 813 & 05 & S84/S94 & 47 & - ve & 0.00097 & 0.0063 & 0.00254 \\
\hline & 08 & S84/S94 & 28 & - ve & 0.00001 & & 0.00316 \\
\hline & 09 & S84/S94 & 23 & $-v e$ & 0.00001 & & 0.00316 \\
\hline 814 & 03 & S85/S80 & 33 & - ve & 0.00025 & 0.0120 & 0.00625 \\
\hline & 04 & S85/S80 & 30 & - ve & 0.00025 & & 0.00625 \\
\hline & 05 & S85/S80 & 30 & - ve & 0.00025 & & 0.00625 \\
\hline & 08 & S $85 / S 80$ & 52 & $-v e$ & 0.77191 & & 0.77791 \\
\hline 817 & 03 & S $84 /$ S 283 & 20 & $-v e$ & $0 \cdot 00004$ & 0.0751 & 0.03759 \\
\hline 819 & 04 & S85/S80 & 28 & $-v e$ & 0.00137 & 0.0763 & 0.03952 \\
\hline 822 & 05 & S85/S125 & 40 & - ve & 0.00030 & 0.0755 & 0.03805 \\
\hline 823 & 04 & S85 & 19 & -ve & $0 \cdot 15758$ & 0.0862 & 0.20068 \\
\hline 824 & 03 & S $84 / S 283$ & 33 & - ve & 0.00004 & 0.0755 & 0.03779 \\
\hline 829 & 04 & S85/S 125 & 36 & -ve & 0.00018 & 0.1235 & 0.06193 \\
\hline 838 & 04 & S $85 / S 145$ & - & ND & 0.00059 & 0.0817 & 0.04144 \\
\hline 848 & 04 & S $84 / \mathrm{S} 125$ & - & ND & 0.00020 & 0.0686 & 0.03450 \\
\hline & 06 & S84/S 125 & - & ND & 0.50000 & & 0.50000 \\
\hline
\end{tabular}

third decade and $1 / 20$ or 0.05 (upper confidence limit 0.14 ) in the fourth decades and above. There was one reported false positive scan, but this did not strictly meet the criteria for a positive diagnosis.

CALCULATION OF INDIVIDUAL RISKS

Table 7 shows that the methods described here can effectively shift the carrier risk for persons at $50 \%$ prior risk of APKD. In this sample of register families, $80 \%$ of subjects could be placed in a low $(<5 \%)$ or high $(>95 \%)$ risk category. For smaller families where linked markers cannot be used, ultrasound scanning is still highly reliable for people over 30 years old. Genetic heterogeneity is not a serious problem in most families. Risks calculated by Mlink are altered by no more than $4.5 \%$ (half the upper confidence limit of the proportion of unlinked disease) in families not informative for flanking markers. Of the three families showing a raised probability of PKD2, only one showed a high likelihood. In the other two families, risks to subjects who had inherited a low risk PKD1 haplotype were raised by approximately $9 \%$ and $7.5 \%$ respectively.

Hopefully the PKD1 gene will be cloned in the near future and mutations characterised. This may still not remove the need for ultrasound and DNA marker studies, if it turns out, as with so many other disease genes, that a wide variety of different mutations occur in the population. Furthermore, differentiating the two or more loci for APKD may still be problematical. In this situation linkage analysis with close markers will continue to be a useful test. In addition ultrasonography will remain a cheap, relatively accurate, and widely available screening tool.

We thank Dr P Harris for markers pNL56 and SM7 and for typing SM6A. In addition we would like to acknowledge the contribution of the European Concerted Action "Towards
prevention of renal failure caused by inherited polycystic kid- 

ney disease", its project leader Dr M Breuning, and its organlarly Dr L Sandkuijl and Mr I Fenton. This work was supported by a UK Department of Health Special Medica Development Project and by the North Western Regional Health Authority.

1 Dalgaard OZ. Bilateral polycystic disease of the kidneys. Acta Med Scand (Suppl) 1957;158:1-251.

2 Dacies F, Coles (Suppl) 1957,158:1-251. AJ, Evans C, Coch population/based study. $Q \mathcal{F}$ Med 1991;79:477-85.

3 Churchill DN, Bear JC, Morgan J, Payne RH, McManamon PJ, Gault H. Prognosis of adult polycystic kidney disease re-evaluated. Kidney Int 1984:26:190-3.

4 Hodgkinson KA, Kerzin-Storrar L, Watters EA, Harris R. Adult polycystic kidney disease: knowledge, experience, and attitudes to prenatal diagnosis. $\mathcal{f}$ Med Gene 1990;27:552-8.

5 Ravine D, Walker RG, Gibson RN, Sheffield LJ, KincaidSmith $\mathrm{P}$, Danks D. Treatable complications in undiagnosed cases of autosomal dominant polycystic kidney disease. Lancet 1991;337:127-9.

6 Bear JC, McManamom P, Morgan J, et al. Age at clinical onset and at ultrasonographic detection of adult polycystic kidney disease. Am F Med Genet 1984;18:45-53.

7 Bear JC, Parfrey PS, Morgan JM, Martin CJ, Cramer BC Autosomal dominant polycystic kidney disease: new information for genetic counselling. Am $\mathcal{f}$ Med Genet 1992;43:548-53.

8 Reeders ST, Breuning MH, Davies KE, et al. A highly polymorphic DNA marker linked to adult polycystic polymorphic DNA marker linked to adult polycystic
kidney disease on chromosome 16. Nature 1985;317:5424.

9 Breuning MH, Snijdewint FGM, Dauwerse JG, et al. Two step procedure for early diagnosis of polycystic kidney step procedure for early diagnosis of polycystic kidney
disease with polymorphic DNA markers on both sides of disease with polymorphic DNA markers

10 Romeo G, Costa G, Catizone L, et al. A second genetic locus for autosomal dominant polycystic kidney disease. Lancet 1988;ii:8-10.

11 Kimberling WJ, Fain PR, Kenyon JB, Goldgar D, Sujansky E, Gabow PA. Linkage heterogeneity of autosomal polycystic kidney disease. $N$ Engl $f \mathrm{Med}$

12 Pieke SA, Kimberling WJ, Kenyon JB, Gabow P. Genetic heterogeneity of polycystic kidney disease: an estimate of the proportion of families unlinked to chromosome 16 . Am $\mathcal{F}$ Hum Genet 1989;45:A58.

13 Parfrey PS, Bear JC, Morgan J, et al. The diagnosis and prognosis of autosomal dominant polycystic kidney disease. $N$ Engl f Med 1990;323:1085-90.

14 Peters DJ, Sandkuijl LA. Genetic heterogeneity of polycys- tic kidney disease in Europe. In: Breuning $\mathrm{MH}$, Devoto $\mathrm{M}$, Romeo G, eds. Contributions to nephrology. Basel: Karger, 1992:128-39.

15 Elles RG, Read AP, Hodgkinson KA, Watters A, Harris $R$. Recombination or heterogeneity: is there a second locus
for adult polycystic kidney disease? $f$ Med Genet for aduit poly $27: 413-17$.

16 Turco A, Peissel B, Quaia P, Morandi R, Bovicelli L, Pignati PF. Prenatal diagnosis of autosomal dominant polycystic kidney disease using flanking DNA markers and the polymerase chain reaction. Prenat Diagn

17 Jarman AP, Nichols RD, Weatherall DJ, Clegg JB, Higgs DR. Molecular characterisation of a hypervariable region downstream of the human alpha globin gene cluster. EMBO f 1986;5:1857-63.

18 Germino GG, Barton NJ, Lamb J, et al. Identification of a locus which shows no genetic recombination with the autosomal dominant polycystic kidney disease gene on chromosome 16. Am $\mathcal{f}$ Hum Genet 1990;46:925-33

19 Harris PC, Barton NJ, Higgs DR, Reeders ST, Wilkie AO. A long range restriction map between the alpha globin complex and a marker closely linked to the polycystic kidney disease 1 (PKD1) locus Genomics 1990;7:195-206.

20 Harris PC, Thomas S, Ratcliffe PJ, Breuning MH, Coto E Lopez-Larrea C. Rapid genetic analysis of families with polycystic kidney disease 1 by means of a microsatellite marker. Lancet 1991;338:1484-7.

21 Thompson $\mathrm{AD}$, Shen $\mathrm{Y}$, Holman $\mathrm{K}$, et al. Isolation and characterisation of (AC)n microsatellite genetic markers from human chromosom 16. Genomics 1992;13:402-8.

22 Breuning MH, Snijdewint FG, Smits JR, Dauwerse JG Saris JJ, van Ommen GJ. A Taql polymorphism identiSaris JJ, van Ommen GJ. A Taql polymorphism identi-
fied by 26-6 (D 16S125) proximal to the locus affecting fied by 26-6 (D16S125) proximal to the locus affecting adult polycystic kidney disease (PKD

23 Hyland VI, Suthers GK, Friend K, et al Probe VK5B is located in the same interval as the autosomal dominant located in the same interval as the autosomal dominant adult polycysti

24 Breuning MH, Reeders ST, Brunner $\mathrm{H}$, et al. Improved early diagnosis of adult polycystic kidney disease with 87;ii:1359-61.

25 Lathrop GM, Lalouel JM. Easy calculations of lod scores and genetic risks on small computers. Am f Hum Gene 1984;36:460-5.

26 Wright AF, Teague PW, Pound SE, et al. A study of genetic linkage heterogeneity in 35 adult-onset polycystic kidney disease families. Hum Genet 1993;90:569-71.

27 Reeders ST, Keith T, Green P, et al. Regional localisation of the autosomal dominant polycystic kidney disease locus. Genomics 1988;3:150-5. 